\begin{tabular}{|c|c|}
\hline \multirow{3}{*}{ 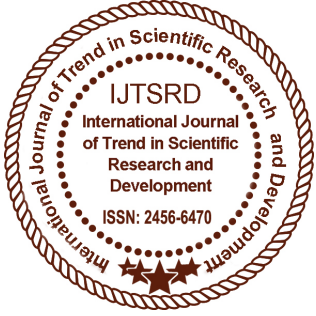 } & $\begin{array}{l}\text { International Journal of Trend in Scientific } \\
\text { Research and Development (IJTSRD) }\end{array}$ \\
\hline & International Open Access Journal \\
\hline & ISSN No: 2456 - 6470 | www.ijtsrd.com | Volume - 2 | Issue - 5 \\
\hline
\end{tabular}

\title{
Experimental Investigation on Solar Powered Auxiliary Automobile Air Conditioning System
}

\author{
M. Ashoka ${ }^{1}$ ， Dr. N. Shenbagavinyagamoorthib ${ }^{2}$ ， Dr. S. Neelakrishnanc ${ }^{3}$ \\ ${ }^{1}$ Lecturer, Nachimuthu, Polytechnic College, Pollachi, \\ ${ }^{2}$ Assistant Professor, Anna University, Thirunelveli, \\ ${ }^{3}$ Professor, PSG College of Technology, Coimbatore, \\ Tamil Nadu, South Chennai, Indian
}

\begin{abstract}
This paper is concerned with experimental investigation on solar energy driven automobile vapor compression air conditioning system fitted in the luggage boot as an auxiliary unit not disturbing the engine driven conventional air conditioning system. An array of $150 \mathrm{~W}$ solar cells is settled on the roof of the car to continuously charge the $24 \mathrm{~V}$ batteries. The $1 / 2 \mathrm{HP}$ open type compressor, the condenser fan and the evaporator blower are run by the current from the solar energy charged batteries.
\end{abstract}

Keyword: Solar Cells; auxiliary unit; Open type compressor; luggage boot; Greenhouse effect.

\section{INTRODUCTION}

The average temperature during the summer typically exceeds $27^{\circ} \mathrm{C}$ in subtropical and tropical regions. Furthermore, the greenhouse effect causes the temperature in automobiles to reach $60^{\circ} \mathrm{C}-70^{\circ} \mathrm{C}$ [13 ] in open parking lots; people cannot usually endure such temperatures comfortably. Moreover, the instrumentation panel, leather seats and plastic accessories, among other items, age rapidly if exposed to these temperatures for a long period [4].

Like other air conditioner systems, the automobile air conditioner must provide adequate comfort cooling to the passenger in the conditioned space under a wide variety of ambient conditions. In automobile air conditioning load factors are constantly and rapidly changing as the automobile moves over highways at different speeds and through all kinds of surroundings. As the car moves faster there is greater amount of infiltration into the car and the heat transfer between the outdoor air and the car surface is increased. The sun baking down on a black top road will raise its temperature to $50^{\circ} \mathrm{C}-60^{\circ} \mathrm{C}$ approximately and thus increases the amount of heat transmitted into the car. When driving through a grassy terrain, much less radiant heat is expected than when passing through sandy flats or rocky hills. Therefore the car is subjected to varying amount of heat load when its orientation changes during the journey.

An automobile engine utilizes only $35 \%$ of available energy and rest are lost to the cooling and exhaust system. If one is adding conventional air conditioning system to the automobile, it further utilizes about $5 \%$ of the total energy. Therefore the automobile becomes costlier, uneconomical and less efficient [5]. Addition of conventional air conditioner in a car also decreases the life of the engine due to abrasion and increases the fuel consumption.

The solar energy module can be employed to absorb solar power and turn it into electric power during driving or parking and charge the battery. The battery runs a DC motor which in turn drives an open type refrigerant compressor producing refrigeration effect. This auxiliary air conditioning system will run nonstop as long as sufficient solar energy is available to charge the battery. The cooling effect produced ensures improved human comfort, increased engine service life, energy conservation and environment protection. 


\section{The concept and the structure of the auxiliary air conditioning unit.}

The power source for the ancillary air conditioning unit is the 1HP DC motor. The current for the DC motor is drawn from a $24 \mathrm{~V}$ battery charged by an array of $150 \mathrm{~W}$ solar cells settled on the car roof top. The DC motor runs a $1 / 2$ HP open type compressor to produce the cooling effect inside the car cabin. The block diagram of the ancillary air conditioning system is shown in Fig. 1. The $24 \mathrm{~V}$ batteries, the $1 \mathrm{HP}$ DC motor, $1 / 2$ HP open type compressor, the condenser coil are assembled in the luggage boot of the car. The evaporator coil is fixed on the inside of the car roof.

The $150 \mathrm{~W}$ single array solar cells are settled on the car roof top. Devices to convert $12 \mathrm{~V}$ from solar cells to $24 \mathrm{~V}$ to battery, to prevent flow of current from battery to solar cells, to prevent battery deep discharge and to step down the voltage to DC motor to have the rated compressor rpm are included in the electrical circuit of the system. The current to drive the condenser fan and the evaporator blower motor are also drawn from the solar cells charged batteries

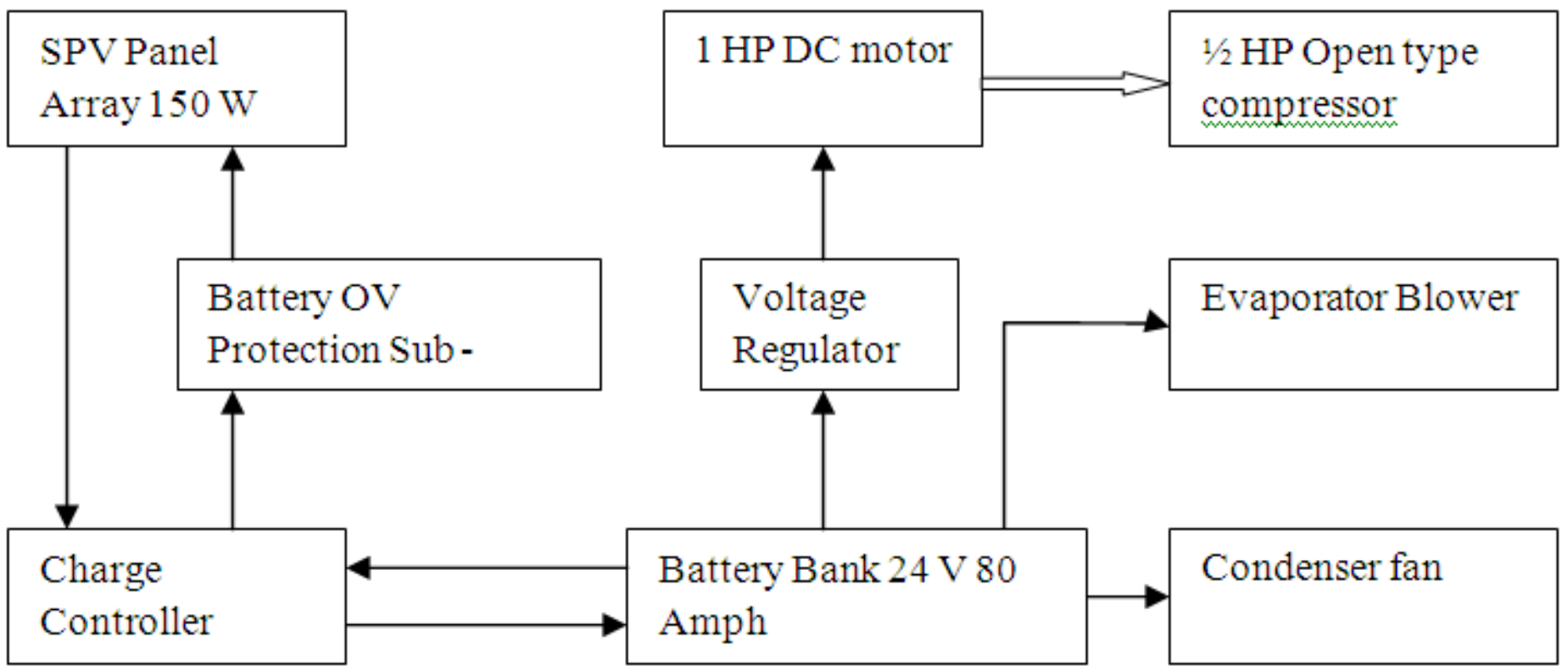

\section{Performance test}

Experimentation was carried out to analyze the performance of the fabricated system by measuring various related parameters.

Fig.1. Block diagram of ancillary air conditioning system

The table 1 shows the current consumption by the evaporator blower, condenser fan and the DC motor. The devices are so selected to make the total current consumption as minimum to increase the battery backup capacity

Table 1. Current consumption by different system devices

\begin{tabular}{|c|c|c|}
\hline SI. No & System Device & Current A \\
\hline 1 & DC Motor & 20 \\
\hline 2 & Condenser & 1.4 \\
\hline 3 & Evaporator Blower & \\
\hline & 1 Low & 0.8 \\
\hline & 2 Medium & 1 \\
\hline & 3 High & 2 \\
\hline
\end{tabular}


International Journal of Trend in Scientific Research and Development (IJTSRD) ISSN: 2456-6470

Table $2 \mathrm{a}, \mathrm{b}$, c. Shows the data acquired by conducting the experiment and the calculated actual COP. The average COP of the system is found to be 0.66

Tab. 2a. COP calculation for Blower fan speed of 3.9m/sec (Low Speed)

\begin{tabular}{|c|c|c|c|c|c|c|c|c|c|}
\hline \multirow{2}{*}{ S. No } & \multirow{2}{*}{$\begin{array}{l}\text { Time } \\
\min \end{array}$} & \multicolumn{2}{|c|}{ Cabin Temp ${ }^{0} \mathrm{C}$} & \multicolumn{3}{|c|}{ Current A } & \multirow{2}{*}{$\begin{array}{c}\text { Total } \\
\text { Current A }\end{array}$} & \multirow{2}{*}{$\begin{array}{l}\text { Power } \\
\text { input W }\end{array}$} & \multirow[b]{2}{*}{$\mathrm{COP}$} \\
\hline & & Initial & Final & Condenser & Blower & $\begin{array}{c}\text { DC } \\
\text { Motor }\end{array}$ & & & \\
\hline 1 & 10 & 40 & 37 & 1.4 & 0.8 & 20 & 22.2 & 400 & 0.70 \\
\hline 2 & 10 & 37 & 32 & 1.4 & 0.8 & 20 & 22.2 & 400 & 0.70 \\
\hline 3 & 10 & 32 & 27 & 1.4 & 0.8 & 20 & 22.2 & 400 & 0.70 \\
\hline
\end{tabular}

Tab. 2b. COP calculation for Blower fan speed of $4.6 \mathrm{~m} / \mathrm{sec}$ (Medium Speed)

\begin{tabular}{|c|c|c|c|c|c|c|c|c|c|}
\hline \multirow{2}{*}{ S. No } & \multirow{2}{*}{$\begin{array}{c}\text { Time } \\
\text { min }\end{array}$} & \multicolumn{2}{|c|}{ Cabin Temp ${ }^{0} \mathrm{C}$} & \multicolumn{2}{|c|}{ Current A } & \multicolumn{2}{c|}{$\begin{array}{c}\text { Total } \\
\text { Current A }\end{array}$} & $\begin{array}{c}\text { Power } \\
\text { input W }\end{array}$ & COP \\
\cline { 3 - 10 } & 10 & 40 & 36 & 1.4 & 1 & 20 & 22.4 & 403 & 0.66 \\
\hline 2 & 10 & 36 & 29 & 1.4 & 1 & 20 & 22.4 & 403 & 0.66 \\
\hline 3 & 10 & 29 & 24 & 1.4 & 1 & 20 & 22.4 & 403 & 0.66 \\
\hline
\end{tabular}

Tab 2c. COP calculation for Blower fan speed of $7.2 \mathrm{~m} / \mathrm{sec}$ (High Speed)

\begin{tabular}{|c|c|c|c|c|c|c|c|c|c|}
\hline \multirow{2}{*}{ S. No } & \multirow{2}{*}{$\begin{array}{c}\text { Time } \\
\text { min }\end{array}$} & \multicolumn{2}{|c|}{ Cabin Temp ${ }^{0} \mathrm{C}$} & \multicolumn{2}{|c|}{ Current A } & \multicolumn{2}{c|}{$\begin{array}{c}\text { Total } \\
\text { Current A }\end{array}$} & $\begin{array}{c}\text { Power } \\
\text { input W }\end{array}$ & COP \\
\cline { 3 - 9 } & 10 & 40 & 35 & 1.4 & 2 & 20 & 23.4 & 421 & 0.61 \\
\hline 1 & 10 & 35 & 32 & 1.4 & 452 & 20 & 23.4 & 421 & 0.61 \\
\hline 3 & 10 & 32 & 23 & 1.4 & 2 & 20 & 23.4 & 421 & 0.61 \\
\hline
\end{tabular}

\section{Result and Discussion}

From fig. 2 the COP is found to decrease with the blower speed although the blower speed increases the rate of fall in temperature as well as the attainment of temperature as low as $23{ }^{\circ} \mathrm{C}$. The battery capacity last for 2.5 hours of continuous operation without the solar cells charging, With charging and discharging taking place simultaneously the charging rate is found to higher than the discharge rate hence ensuring continuous running of the system

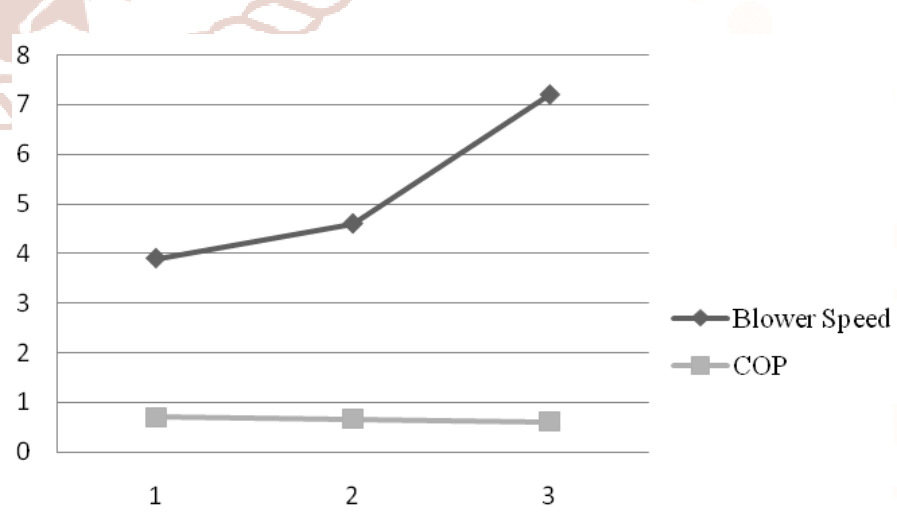

Fig. 2. COP variation with Blower speed 


\section{Conclusion}

The concept running an auxiliary car air conditioning system using solar energy is proved successful and feasible. This system will be more useful during sun soaking of the vehicle as it pull down the temperature appreciably reducing the pull down load on the conventional engine fitted air conditioner. This not only increase vehicle mileage but also increase the life of the engine due to less wear and tear. It will increase the passenger comfort even while parking and the engine not running. As the cabin temperature in no Circumstances shoot beyond the ambient temperature the interior furnishings do not age quickly.

6. References

1. Sasaki, Yokota M, Nagayoshi H, Kamisako K. Evaluation of electric motor and gasoline engine hybrid car using solar cell. Solar Energy Mater Solar Cells 1997; 47:259-63

2. Garner IF, Solems SA. Vehicle auxiliary power application for solar cells. Automobile Electronics 1991:187 - 91

3. Brot DL, Burch SD, Keyser MA. Opportunities to Reduce Vehicle Climate Control Loads, National Renewable Energy Laboratory, EVS - 15 Conference; 1998

4. David Huang K, Sheng - Chung Tzeng, Wei Ping Ma, Ming - Fung Wu. Intelligent Solar Powered automobile - ventilation system. Applied Energy 80 (2005) 141 - 154

5. Shah Alam. A Proposed Model for Utilizing Exhaust Heat to run Automobile Air conditioner. The $2^{\text {nd }}$ Joint International Conference on "Sustainable Energy and Environment (SEE 2006)", 21 - 23 November 2006, Bangkok, Thailand 